\title{
ANALYSIS OF MOBILE COMMERCE PERFORMANCE BY USING THE TASK- TECHNOLOGY FIT
}

\author{
Kun Chang Lee ${ }^{1}$, Sangjae Lee ${ }^{2}$ and Jin Sung $\mathrm{Kim}^{3}$ \\ ${ }^{1}$ School of Business Administration, Sungkunkwan University, Seoul 110-745, Korea, \\ leekc@skku.ac.kr
}

${ }^{2}$ Department of E-Business, Sejong University, Seoul 143-747, Korea, kt_sjlee@hanmail.net

${ }^{3}$ School of Business Administration, Jeonju University, Jeonju, Jeonbuk 560-759, Korea, kimis@ij.ac.kr

Abstract: The rapid growth of investments in mobile commerce (M-commerce) to reach a large and growing body of customers, coupled with low communication costs, has made user acceptance an increasingly critical management issue. The study draws upon the task-technology fit (TTF) model as its theoretical basis and its empirical findings to pragmatically explain the key factors that affect the performance and user acceptance of M-commerce. A total of 110 usable responses were obtained. The findings indicate that the task, technology, and individual user characteristics positively affect tasktechnology fit and M-commerce usage. The task-technology fit and Mcommerce usage are the dominant factors that affect M-commerce performance. The result points out the importance of the fit between technologies and users' tasks in achieving individual performance impact from $\mathrm{M}$-commerce. This paper identifies pertinent issues and problems that are critical in the development of M-commerce.

Key words: $\quad$ Mobile, M-Commerce, Task-Technology Fit (TTF) 


\section{INTRODUCTION}

Mobile commerce is an emerging discipline that involves mobile devices, middleware, protocols, and wireless networks. Internet-based M-commerce has received considerable attention because of its potential organizational impact. Various business communities have announced plans for $\mathrm{M}$ commerce enhancements in business transactions, as mobile telephony now allows the potential platform for unprecedented penetration of the mobile communication services. In addition, a great number of organizations have used mobile communication services and M-commerce for business purposes in order to stand a better chance of achieving their competitive advantage. For instance, NTT DoCoMo, Vodafone, Verizon, Sprint PCS, and AT\&T Wireless provide "cyber-mediation" and great efficiency in supplies and marketing channels through mobile commerce. The benefits of an M-commerce include: more efficient payment systems, reduced time to market new products and services, improved market reach, and customization of products and services (Barnes, 2002; Senn, 2000).

M-commerce applications involve transmitting payment details, requesting information, receiving specific content, or retrieving status information over mobile communication devices. For instance, airlines are now developing technology that will alert passengers, especially frequent fliers, to schedule changes, seat upgrades, and so on, through wireless devices. Recently, the electronic commerce applications provided by mobile communication services include mobile information agents (Mandry et al., 2001; Omicini and Zambonelli, 1998), online kiosks (Slack and Rowley, 2002), government applications (e.g., online selling by the postal service and web-based electronic data interchange in trade applications) and direct online shopping, such as Internet-based (or web-based) shopping malls and Internet-based stock markets. Travel-related and hobby-related sites that provide leisure information are also among the common websites available through mobile communication services. Since 1997, when cyber trading was first allowed, there has been a continuous growth in Internet-based stock trading systems through mobile communication services in Korea. Electronic cyber trading was utilized by Korean securities companies in processing more than $50 \%$ of all transactions in 1999. In two or three years, it is predicted that more than $80 \%$ of all transactions will be done over the Internet (Moon and Ahn, 1999).

In the US, the current rush in using wireless communications was triggered by the US Federal Communication Commission's auctioning of

personal communication-service spectrum space (Senn, 2000). The collaboration of both the public and private sectors has facilitated the development of mobile commerce. 
In Korea (Republic of), public organizations, such as the Ministry of Information and Communication, and the Ministry of Industry Resources, and private organizations sponsored by the government, such as Korea Telecom, Dacom, and SK-Telecom, have provided the basic telecommunications infrastructure. Private sector organizations include retailers, banks, stock investment companies, system integration companies, and entertainment companies. The development of M-commerce in Korea is clearly an innovation in the way commercial transactions between businesses and consumers are conducted. Among the three distinct identifiable classes of EC applications (Applegate et al., 1996) - business-tocustomer, business-to-business, and intra-organization - M-commerce deals with the business-to-customer class. M-commerce provides a web presence with information about a company, product, or service, and facilities for purchasing, which may be online or conventional. M-commerce also provides another web presence that has information on specific matters, such as entertainment, real estate, or financial investment, and encourages potential customers to spend while using such information.

The objectives of this study were: (1) to develop a TTF model for Mcommerce performance, (2) to examine the direct effect of these determinants by using a structural equation model, and (3) to test measurement and its structural models.

\section{TTF AND M-COMMERCE PERFORMANCE}

IT adoption and usage is a phenomenon in its own right (Davis, 1989; Mathieson, 1991; Moore and Benbasat, 1991; Thompson et al., 1991; Hartwick and Barki, 1994). Researchers have studied the impact of users' individual beliefs and attitudes on usage behavior (DeSanctis, 1983; Fuerst and Cheney, 1982; Srinivasan, 1985), and how these individual beliefs and attitudes, in turn, influenced various external factors, such as the technical design (Benbasat and Dexter, 1986; Dickson et al., 1986; Malone, 1981), the type of system development process used (King and Rodriguez, 1981), user involvement in system development (Franz and Robey, 1986), and the nature of implementation such system (Vertinsky et al., 1975).

Studies linking technology and performance employed user attitudes and beliefs to predict the degree of utilizing current information systems. From the Diffusion of Innovation perspective (Tornatzky and Klein, 1982), researchers suggested a variety of factors that affect IT adoption and usage: innovation (Hoffer and Alexander, 1992; Moore, 1987), individual users (Brancheau and Wetherbe, 1990), and communication channels (Nilikanta and Scammell, 1990). 
The literature suggested the task and its impact on system usage or user performance. A technology was more useful if it provided features that fit the requirements of a task (Culnan, 1983; Daft and Macintosh, 1981). At the organization level, researchers have linked "fit" and utilization (Cooper and Zmud, 1990; Tornatzky and Klein, 1982). At the individual user level, a "system/work fit" construct has been proposed as a critical determinant in managerial electronic workstation use (Flyoid, 1986). The impact of data representation on performance is dependent upon its fitness with the task (Benbasat et al., 1986; Dickson et al., 1986). Kim (1988) suggested that the performance of a sub-unit of IS was determined by its coordination modes, but was contingent upon the task in terms of task predictability, problem analyzability, and task interdependence. Raymond, et al. (1994) investigated the correlation between technology-structure fit and organizational performance based on the contingency theory. Lai (1999) suggested that the performance of IS professionals was dependent upon the CASE-task fit. The IS developers' performance would be more effective when the CASE tool was compatible with the IS and the corresponding task contexts.

The link between "cognitive fit" and performance has been supported by laboratory experiments (Jarvenpaa, 1989; Vessey, 1991). Decision-making performance slowed down as the mismatches between data representations and tasks demanded additional translations between data representations or decision processes (Vessey, 1991). This was based on the cost-benefit perspective, which asserted that individuals weighed benefits (impact on correctness, speed, and justifiability) and costs (mental effort on information acquisition and computation), before they chose a strategy for processing the information in decision-making (Goodhue, 1995; Creyer et al., 1990). Information systems positively affected performance when functionality met the task requirements of users. There existed a more general "fit" theory of tasks, individual user characteristics, and performance (Goodhue, 1988).

TTF has been defined as the extent to which technology functionality matched task requirements and individual user abilities (Goodhue, 1995). A number of researchers have proposed that performance would result from task-technology fit. Organizational structure contingency theories that proposed the organization's structure must "fit" its organizational context to have some similarity to TTF (Goodhue, 1995). While TTF is at the individual level, the structural contingency theory is at the organizational level. 


\section{INDIVIDUAL USER CHARACTERISTICS, TTF, AND PERFORMANCE}

Goodhue (1998) suggested the basic model of TTF with moderating effects. This model suggested the different information systems functionalities required by users for a certain task, which then served as the basis for a "task-technology fit" instrument. The instrument thus measured the degree to which an organization's information systems and services were meeting the information needs of its managers. In this research model, we should focus on the construct known as individual user characteristics. Goodhue (1998) assumed and validated a hypothesis that the task characteristics and individual user characteristics directly affected TTF. In addition, they "moderated" the strength of the link between specific characteristics of information systems and users' evaluations of those information systems. Therefore, we could determine how individual user characteristics affect the performance of TTF and users' satisfaction with those information systems. Figure 1 shows Goodhue's TTF model (1998).

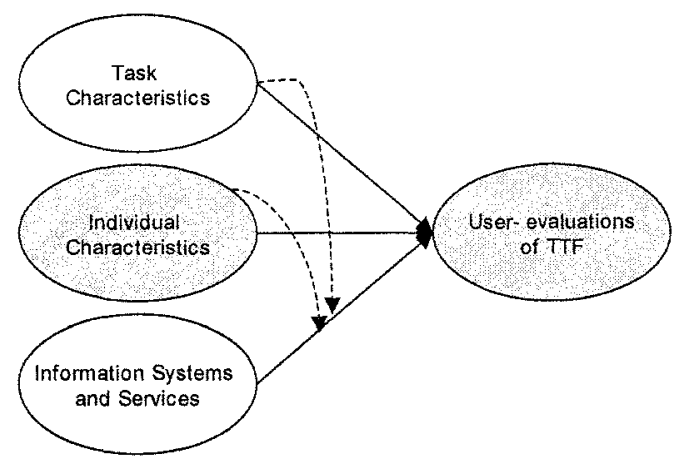

Figure 1. The basic model of TTF

Individual user characteristics, as suggested by Goodhue (1998), were defined as the user's ability in managing information systems. In this point of view, we focused on end-user ability. Therefore, we found Lee, et al.'s causal model (1995) helpful. In the study, they suggested the relationship among the end-user's ability, information system acceptance, training, and effectiveness. The heart of this research focused on the end-user's ability to affect system utilization, information system (IS) acceptance, job satisfaction, and over-all IS satisfaction. Figure 2 represents these relationships. 


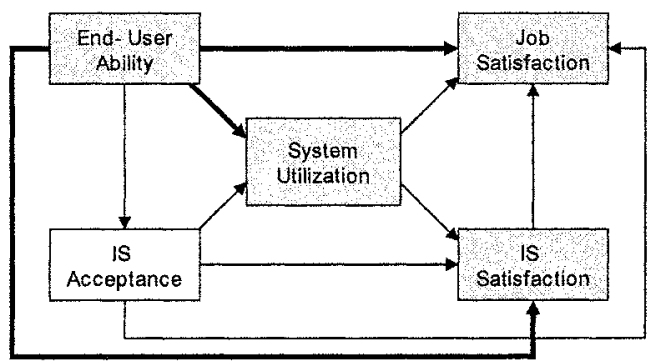

Figure 2. A causal model of end-user training

Baldwin and Rice (1997), similar to this research, suggested a research model based on individual user characteristics and performance. Baldwin and Rice (1997) suggested that the individual user characteristics of securities analysts influenced their use of information sources and communication channels. Figure 3 presents the model of the proposed relationships among individual, institutional, source/channel, and outcome variables.

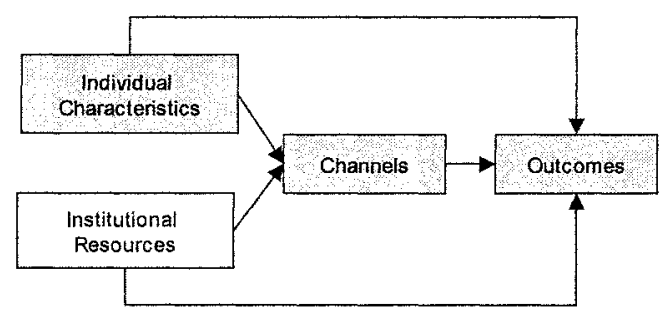

Figure 3. Baldwin and Rice (1997)'s research model

In these researches, we could conclude that many researchers had considered individual user characteristics as an important construct to enhance information systems' utilization and performance, and users' satisfaction. Therefore, we combined the above-mentioned researches into our research model, which was based on individual user characteristics, system utilization, performance, and TTF. In the next chapter, we will be presenting our research model. 


\section{RESEARCH MODEL}

Our research model concerning relationships among variables is developed and presented in Figure 4. The research model addresses the application of the TTF model to M-commerce.

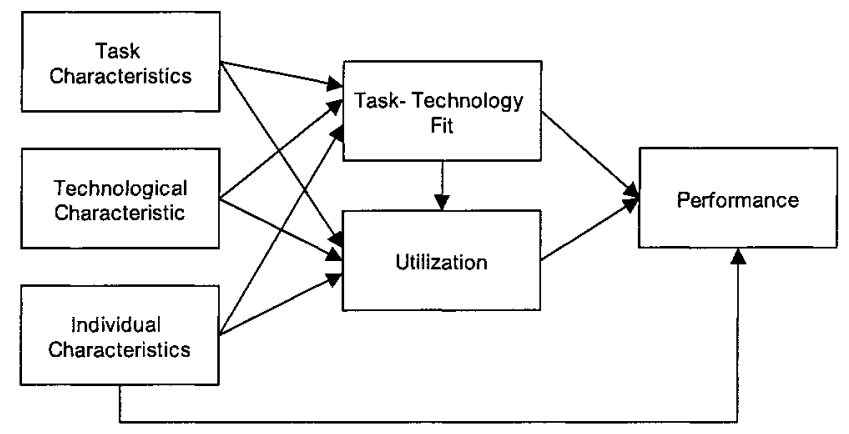

Figure 4. Research model

This study mainly deals with the updated version of the TTF model for $\mathrm{M}$-commerce, as the studies concerning a knowledge management issue in the context of the TTF model are rare. The ultimate goal of M-commerce is to derive user benefits. From multiple vantage points, task, technology, and individual user characteristics are indicated as fundamental and distinct constructs that are influential in determining TTF, the utilization of Mcommerce, and M-commerce performance. Hypotheses used in this study were summarized as follows:

H1: Task characteristics directly affect TTF in M-commerce.

H2: Technology characteristics directly affect TTF in M-commerce.

$H 3$ : Individual user characteristics directly affect TTF in M-commerce.

$H 4$ : Task characteristics directly affect the utilization of M-commerce.

H5: Technology characteristics directly affect the utilization of M-commerce.

H6: Individual user characteristics directly affect the utilization of M-commerce.

$H 7$ : TTF directly affects the performance of M-commerce.

$H 8$ : The utilization of $\mathbf{M}$-commerce directly affects its performance.

$H 9$ : Individual user characteristics directly affect the performance of M-commerce.

H10: TTF directly affects the utilization of M-commerce.

The task, technology, and individual user characteristics all affect the utilization of M-commerce, as well as TTF. In addition, TTF affects the utilization of M-commerce. M-commerce should be used comprehensively to support user tasks, individual users, and upper-level management, and to facilitate the widespread transfer of the technology to other departments in 
the organization. The user's needs, as well as the task requirements, must be satisfied to attain the system objectives through the integration of information with external networks. Internal applications, such as accounts payable and receivable systems, may be efficiently processed in conjunction with an M-commerce system. The rapid and accurate transmission of shipping notices to the production department is critically important in eliminating the need for a large inventory of safety stocks. To compress cycle time and improve data integrity for the rapid transmission of data, the supplier's computers must be integrated with that of the customer's.

The "utilization of mobile communication services" indicates the extent to which $\mathrm{M}$-commerce is used and spread throughout an organization. The IS success model by DeLone and McLean (1992) suggested that IS usage is positively related to other measures of IS success, such as user satisfaction, and individual and organizational impact. However, it has also been argued that system usage and perceived system effectiveness may not always be positively interrelated (Srinivasan, 1985). For instance, the extent of usage would be a misleading indicator of success if the system were considered as a service rather than a product developed to help managers to perform more effectively (Ginzberg, 1978), or if the system were implemented as a reaction to the influence of external parties (e.g., industry associations, government, etc.). There might be no alternative, but to use that system to effectively complete the task. Furthermore, the utilization of M-commerce, as a measure of M-commerce success, only makes sense when system implementation is voluntary, rather than compulsory. The growing use of $\mathrm{M}$ commerce through requests by external influential companies or industry influences makes it an inappropriate surrogate for M-commerce success.

TTF and the utilization of M-commerce affect M-commerce performance. Innovation is implemented over a long time, while adoption is a single event. IS implementation is an organizational effort directed toward diffusing information technology within an organization (Cooper and Zmud, 1990). After an organization has formally adopted an IS, its implementation has to proceed comprehensively within the organization to start reaping benefits. The IS should be integrated to support the widespread transfer of its technology to various applications, which could then significantly redesign the business process (Premkumar et al., 1994). The full potential of the IS could be realized as the advocates of its implementation (or innovation) gain wider acceptance (Swanson, 1994). This could not be obtained by merely automating the process of transaction or the communication procedures. IS implementation would tend to be increasingly more elaborate with additional business functions, as users' needs are identified and met by various extensions and enhancements. Organizations might derive full benefits from 
an inter-organizational system (IOS) by expanding external services and electronic links to attain economies of scale (Vitale, 1985).

The positive effects of IS implementation on performance have been consistently proven. For example, the integration of information collected through EDI with internal IS applications has been asserted as a critical factor for system effectiveness and efficiency (Iacovou et al., 1995; Premkumar et al., 1994). The integration of M-commerce with internal applications could lead to better customer service and improved inter-firm relationships because rapid and accurate information were provided to customers. The adoption and implementation of M-commerce may impose significant one-time costs on an organization, as its internal systems must be adjusted to allow an interface with its trading partners. It would be difficult to obtain significant benefits from a costly change in business processes unless volume has reached a level sufficient enough to warrant change. The transaction volume should be large enough to cover the initial high investment cost, and then reduce administrative costs. The goals of many $\mathrm{M}$ commerce users include increasing sales and replacing paper documents and verbal-based commerce methods with online transactions, thus reducing order costs and cycle time. These aims would not be achieved without a substantial shift in the use of the system, which would be possible with the use of high TTF. M-commerce users could obtain only transitional benefits after moving only a limited portion of their total transactions to the new system.

\section{METHODOLOGY}

Data for this research were collected through interviews with Mcommerce managers. Each respondent was asked a series of questions under a structured interview format. Each interview lasted approximately an hour.

The structured interview was the primary data collection method. Target respondents were selected as follows: Persons, who were employed in companies that used M-commerce extensively, were identified. From publicly available company databases (through the Chollian network service), the companies that frequently contact customers in their business activities were selected. The employees of the companies were randomly contacted to assess their level of M-commerce usage.

Three hundred mails were sent by post, and 200 more were sent through E-mail. Two hundred fifteen replied, and among these, the respondents who used M-commerce more than once a month and transacted online for more than 10 minutes per month were selected. One hundred ten mails drew target respondents. The over-all response rate was high because participation in the 
survey was solicited through direct visits to M-commerce managers. Also, the objectives of the study were clearly explained to them.

The questionnaire was tested for validity and reliability. Content validity was established through a literature review on the Internet and IS implementation. The items were pre-tested with both practitioners and experts to enhance the content validity of the instrument. Several minor modifications were made based on feedback regarding the presentation of the survey and the clarity of several items. The survey was then deemed ready for actual respondents after no major comments were made.

Reliability and construct validity of the measures were evaluated using the Cronbach alpha and factor analyses. The three commonly employed rules to identify factors - a minimum eigen value of 1 , simplicity of structure, a minimum factor loading of 0.5 - were followed (Hair et al., 1979). The items that failed the factor analysis were dropped.

The final principal component in the factor solution with a varimax rotation produced a five-factor solution that explained 70 percent of the systematic covariance among the scale items. All empirically derived factors had eigen values greater than one. Tables 1 and 2 show the descriptive statistics of the items and the results of the confirmatory factor analysis. The factor analysis and the reliability tests suggest that the factor structure of the variables is stable, and provide the evidence for the construct validity of the given measures.

Four items, which represent the complexity and understandability of the work process, measure the task characteristics. The items are adapted from Perrow (1967) and Withey (1993). The technology characteristics are measured by four items, which represent the perceived quality of mobile technology. The items are based on Hage and Aiken (1970), and Jarvenpaa and Ives (1991). The individual user characteristics are measured by five items, which intend to measure user attitudes toward the use of technology. TTF indicates fitness between task and technology. The 15 items for TTF are based on Goodhue and Thompson (1995), and represent perceived usefulness, ease of use, perceived benefits, and customer satisfaction. The utilization of M-commerce indicates the extent of the usage of M-commerce. The three items for the utilization of M-commerce are based on Davis et al. (1989), Thompson et al. (1994), and Trice and Treacy (1988).

Three items measure the performance of M-commerce, based on Davis et al. (1989) and Goodhue and Thompson (1995). The three items represent the extent of improving work effectiveness and efficiency from using $\mathrm{M}$ commerce. 
Table 1. Descriptive statistics of variables

\begin{tabular}{|c|c|c|c|c|c|}
\hline \multicolumn{2}{|c|}{$\begin{array}{l}\text { Variables (Constructs) } \\
\text { \& Sub-constructs }\end{array}$} & \multirow{2}{*}{ Item } & \multirow{2}{*}{\begin{tabular}{|l|} 
Description \\
M-commerce requires very simple knowledge to use. is \\
\end{tabular}} & \multirow{2}{*}{$\begin{array}{c}\text { Mean } \\
4.4 \\
\end{array}$} & \multirow{2}{*}{ STD } \\
\hline \multirow{3}{*}{$\begin{array}{c}\text { Task } \\
\text { characteristics }\end{array}$} & & & & & \\
\hline & & $\mathrm{TC} 2$ & $\begin{array}{l}\text { The complex decision making process is not necessary to } \\
\text { use M-commerce. }\end{array}$ & 4.5 & 1.1 \\
\hline & & $\mathrm{TC} 3$ & Users need not think deeply when using M-commerce. & 4.5 & 1.1 \\
\hline \multirow{3}{*}{$\begin{array}{l}\text { Technology } \\
\text { characteristics }\end{array}$} & & TE1 & $\begin{array}{l}\text { M-commerce facilitates the communication between } \\
\text { people. }\end{array}$ & 4.4 & 1.3 \\
\hline & & TE2 & $\begin{array}{l}\text { The procedure of functions in M-commerce is very } \\
\text { obvious. }\end{array}$ & 4.2 & 1.2 \\
\hline & & TE3 & $\begin{array}{l}\text { M-commerce excels other technology in providing and } \\
\text { retrieving information. }\end{array}$ & 4.1 & 1.3 \\
\hline \multirow{4}{*}{$\begin{array}{l}\text { Individual } \\
\text { characteristics }\end{array}$} & & ICl & Users are familiar with using M-commerce. & 3.7 & 1.4 \\
\hline & & IC2 & Users have appropriate knowledge to use M-commerce. & 3.9 & 1.3 \\
\hline & & $\mathrm{IC} 3$ & Users generally use M-commerce frequently. & 3.6 & 1.4 \\
\hline & & IC4 & M-commerce helps users find the right information. & 3.9 & 1.4 \\
\hline \multirow{15}{*}{ TTF } & \multirow{4}{*}{$\begin{array}{l}\text { Perceiv } \\
\text { ed } \\
\text { usefuln } \\
\text { ess }\end{array}$} & PU1 & $\begin{array}{l}\text { The work performance will be improved by using } \mathrm{M} \text { - } \\
\text { commerce. }\end{array}$ & 4.1 & 1.5 \\
\hline & & PU2 & $\begin{array}{l}\text { The work productivity will be improved by using } \mathrm{M}- \\
\text { commerce. }\end{array}$ & 4.3 & 1.5 \\
\hline & & PU3 & $\begin{array}{l}\text { The work efficiency will be improved by using } \mathrm{M} \text { - } \\
\text { commerce. }\end{array}$ & 4.4 & 1.5 \\
\hline & & PU4 & M-commerce is very useful in performing work process. & 4.3 & 1.5 \\
\hline & \multirow{3}{*}{$\begin{array}{l}\text { Ease of } \\
\text { use }\end{array}$} & EU1 & It is very easy to do business through mobile commerce. & 4.2 & 1.4 \\
\hline & & EU2 & It is very easy to manage $\mathrm{M}$-commerce. & 4.1 & 1.3 \\
\hline & & EU3 & It is very easy to use M-commerce. & 4.1 & 1.3 \\
\hline & \multirow{5}{*}{$\begin{array}{l}\text { Perceiv } \\
\text { ed } \\
\text { benefit }\end{array}$} & PR1 & $\begin{array}{l}\text { Mobile commerce is very friendly way to buy goods and } \\
\text { service. }\end{array}$ & 4.2 & 1.3 \\
\hline & & PR2 & M-commerce helps better control business process. & 4.1 & 1.3 \\
\hline & & PR3 & M-commerce helps efficiently manage business process. & 4.3 & 1.3 \\
\hline & & PR4 & M-commerce is a convenient way to do business. & 4.5 & 1.3 \\
\hline & & \begin{tabular}{|l|l|} 
PR5 \\
\end{tabular} & M-commerce is a useful way to do business. & 4.6 & 1.3 \\
\hline & \multirow{3}{*}{$\begin{array}{l}\text { User } \\
\text { satisfac } \\
\text { tion }\end{array}$} & SA1 & $\begin{array}{l}\text { Users are generally satisfied with the service provided by } \\
\text { M-commerce. }\end{array}$ & 3.9 & 1.2 \\
\hline & & $\mathrm{SA} 2$ & $\begin{array}{l}\text { Users are generally satisfied with the technology of M- } \\
\text { commerce. }\end{array}$ & 3.8 & 1.2 \\
\hline & & $\mathrm{SA} 3$ & $\begin{array}{l}\text { Users are generally satisfied with the way of doing } \\
\text { business through mobile commerce. }\end{array}$ & 3.9 & 1.2 \\
\hline \multirow{3}{*}{ Utilization } & & UT1 & Users consider using M-commerce very positively. & 4.3 & 1.4 \\
\hline & & UT2 & It is a very good decision to use M-commerce. & 4.2 & 1.2 \\
\hline & & UT3 & Users are willing to use M-commerce continuously. & 4.3 & 1.3 \\
\hline \multirow{3}{*}{ Performance } & & PI1 & $\begin{array}{l}\text { M-commerce has a strong and positive influence on the } \\
\text { user work process. }\end{array}$ & 4.0 & 1.3 \\
\hline & & PI2 & $\begin{array}{l}\text { M-commerce greatly contributes to the improvement of } \\
\text { user work process. }\end{array}$ & 4.0 & 1.3 \\
\hline & & PI2 & $\begin{array}{l}\text { Users will use M-commerce to improve work } \\
\text { performance. }\end{array}$ & 4.1 & 1.3 \\
\hline
\end{tabular}


Table 2. The results of confirmatory factor analysis

\begin{tabular}{|c|c|c|c|c|c|}
\hline Variables & Item & FL & CR & VE & NFI \\
\hline \multirow{3}{*}{$\begin{array}{c}\text { Task } \\
\text { Characteristics }\end{array}$} & $\mathrm{TC} 1$ & 0.608 & \multirow{3}{*}{0.95} & \multirow{3}{*}{0.85} & \multirow{3}{*}{1.00} \\
\hline & $\mathrm{TC2} 2$ & 0.856 & & & \\
\hline & TC3 & 0.819 & & & \\
\hline \multirow{3}{*}{$\begin{array}{l}\text { Technology } \\
\text { Characteristics }\end{array}$} & TE1 & 0.989 & \multirow{3}{*}{0.89} & \multirow{3}{*}{0.81} & \multirow{3}{*}{0.91} \\
\hline & TE2 & 0.843 & & & \\
\hline & TE3 & 0.497 & & & \\
\hline \multirow{13}{*}{ TTF } & SA1 & 0.550 & \multirow{13}{*}{0.98} & \multirow{13}{*}{0.77} & \multirow{13}{*}{0.90} \\
\hline & SA2 & 0.443 & & & \\
\hline & SA3 & 0.538 & & & \\
\hline & EU1 & 0.756 & & & \\
\hline & EU2 & 0.741 & & & \\
\hline & EU3 & 0.833 & & & \\
\hline & PR1 & 0.698 & & & \\
\hline & PR2 & 0.645 & & & \\
\hline & PR3 & 0.745 & & & \\
\hline & PU1 & 0.658 & & & \\
\hline & PU2 & 0.527 & & & \\
\hline & PU3 & 0.580 & & & \\
\hline & PU4 & 0.538 & & & \\
\hline \multirow{3}{*}{ Utilization } & UT1 & 0.826 & \multirow{3}{*}{0.95} & \multirow{3}{*}{0.87} & \multirow{3}{*}{1.00} \\
\hline & UT2 & 0.915 & & & \\
\hline & UT3 & 0.887 & & & \\
\hline \multirow{3}{*}{ Performance } & PI1 & 0.800 & \multirow{3}{*}{0.94} & \multirow{3}{*}{0.84} & \multirow{3}{*}{1.00} \\
\hline & PI2 & 0.825 & & & \\
\hline & PI2 & 0.625 & & & \\
\hline \multirow{4}{*}{$\begin{array}{c}\text { Individual } \\
\text { Characteristics }\end{array}$} & $\mathrm{ICl}$ & 0.719 & \multirow{4}{*}{0.96} & \multirow{4}{*}{0.85} & \multirow{4}{*}{0.99} \\
\hline & IC2 & 0.877 & & & \\
\hline & IC3 & $0.6 \overline{17}$ & & & \\
\hline & IC4 & 0.794 & & & \\
\hline
\end{tabular}

\section{RESULTS}

Table 3 shows that the selected respondents are predominantly in the ages of 20 30, male, college graduates, and have annual salaries ranging from 100 to 300 thousand dollars. The respondents are fairly diverse in terms of age, educational background, job, and salary. This result is in line with the fact that innovative customers are more likely to use M-commerce due to the Internet's global connectivity, improved market reach, low communication and purchasing costs, and creation of new market opportunities. Table 4 suggests the correlation analysis of variables.

This study tests the structural relation between variables using LISREL. LISREL provides several advantages over other multivariate techniques. First, it can validate a causal link, rather than showing a mere empirical association among variables. It can also express intricate causal links, 
including recursive or non-recursive relations, among latent variables to better characterize real-world processes. These links help the development of a theory (Blalock, 1969), but these same relationships cannot be tested by other multivariate techniques.

Table 3. Demographic profile of samples

\begin{tabular}{|c|c|c|c|c|c|c|c|}
\hline & Categories & Count & $\%$ & & Categories & Count & $\%$ \\
\hline \multirow[b]{2}{*}{ Sex } & Male & 73 & 66 & \multirow[t]{5}{*}{ Job } & Public officer & 3 & 3 \\
\hline & Female & 37 & 34 & & $\begin{array}{l}\text { Employee of private } \\
\text { company }\end{array}$ & 53 & 48 \\
\hline \multirow{4}{*}{ Age } & $20-30$ & 42 & 38 & & $\begin{array}{l}\text { Specialized job } \\
\text { (doctor, lawyer, etc.) }\end{array}$ & 46 & 42 \\
\hline & $30-40$ & 59 & 54 & & Student & 4 & 4 \\
\hline & $40-50$ & 6 & 5 & & Others & 4 & 4 \\
\hline & $50-60$ & 3 & 3 & \multirow[t]{6}{*}{ Wage } & Less than $1000 \$$ & 8 & 7 \\
\hline \multirow{5}{*}{ Education } & High school & 10 & 9 & & $100-200$ thousand $\$$ & 47 & 43 \\
\hline & University Student & 9 & 8 & & $200-300$ thousand $\$$ & 49 & 45 \\
\hline & \begin{tabular}{|l|} 
College graduate \\
\end{tabular} & 60 & 55 & & $300-400$ thousand $\$$ & 2 & 2 \\
\hline & MS or $\mathrm{PhD}$ & 31 & 28 & & $400-500$ thousand $\$$ & 3 & 3 \\
\hline & & & & & $500-1000$ thousand $\$$ & 1 & 1 \\
\hline
\end{tabular}

Table 4. Correlation analysis $(* * \mathrm{p}<0.01)$

\begin{tabular}{|l|l|l|l|l|l|l|}
\hline Variables & $\begin{array}{c}\text { TC: Task } \\
\text { characteristics }\end{array}$ & $\begin{array}{c}\text { TE: Technology } \\
\text { characteristics }\end{array}$ & $\begin{array}{c}\text { IC: Individual } \\
\text { characteristics }\end{array}$ & TTF & $\begin{array}{c}\text { UT: } \\
\text { Utilization }\end{array}$ & $\begin{array}{c}\text { PF: } \\
\text { Performance }\end{array}$ \\
\hline TC & 1 & & & & & \\
\hline TE & 0.0942 & 1 & & & & \\
\hline IC & 0.0160 & $0.4935^{* *}$ & 1 & & & \\
\hline TTF & $0.3178^{* *}$ & $0.4477^{* *}$ & $0.2959^{* *}$ & 1 & & \\
\hline UT & $0.3459^{* *}$ & $0.4670^{* *}$ & $0.3792^{* *}$ & $0.7425^{* *}$ & 1 & \\
\hline PF & $0.2479^{* *}$ & $0.4977^{* *}$ & $0.3983^{* *}$ & $0.6396^{* *}$ & $0.7148^{* *}$ & 1 \\
\hline
\end{tabular}

The structural model is represented in Figure 5. The latent variables are enclosed in circles or ellipses. A one-way path between variables indicates a hypothesized direct effect of one variable upon another. If there is no arrow or link between two variables, it means that one variable does not have a direct effect on another.

The chi-square is 7.108 for the given model. The model's goodness of fit index is 0.979 , which is a measure of the relative amount of variables and co-variances of the model. The adjusted goodness of fit is 0.888 . The root mean square residual is 0.039 , which is the average of the residuals. These measures of overall fitness indicate the explanatory power of the model.

Significant causal coefficients are found in the path: from task characteristics and technology characteristics to TTF; from task characteristics and individual user characteristics to utilization; from individual user characteristics, TTF, and utilization to performance; and from TTF to utilization. TTF and the extent of high utilization of M- 
commerce have led to the improved performance of the system. The results support hypotheses $1,2,4,6,7,8,9$, and 10 .

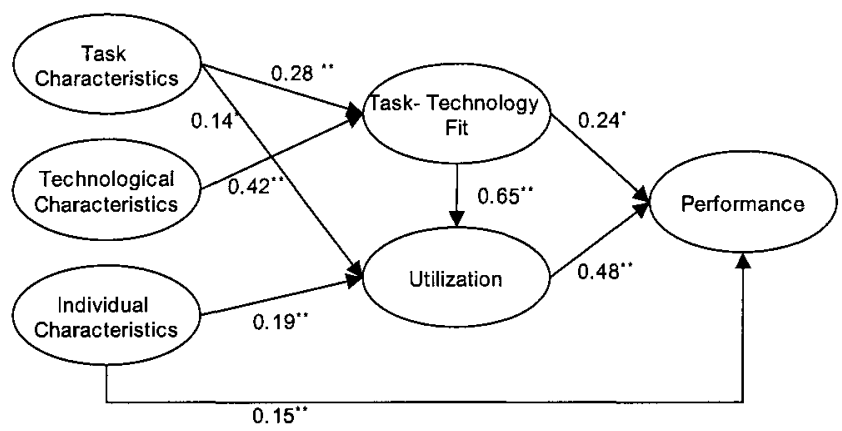

Figure 5. Causal path model $(* \mathrm{p}<0.05, * * \mathrm{p}<0.01)$ Chi-square $=7.108$, $\mathrm{p}=0.130, \mathrm{GFI}=0.979, \mathrm{AGFI}=0.888, \mathrm{NFI}=0.973, \mathrm{RMSR}=0.039$

The positive influences of individual user characteristics, TTF, utilization, and performance indicate that an individual's progress in handling its business transactions through $\mathrm{M}$-commerce is related to an increase in sales and improvement in customer service. Further, the use of sophisticated functions and services (e.g., ordering processes and authentication services) is related to the extent of perceived usefulness, benefit, customer satisfaction, and system profitability. The extent of providing TTF is directly related to ease of use and customer satisfaction. Companies provide information mainly to satisfy customers' needs to know the task and technology characteristics, which help improve customer service.

\section{CONCLUDING REMARKS}

The research findings offer significant academic and practical contributions in planning M-commerce. They provide practical value for evaluating M-commerce in terms of whether they fit the user's tasks, which means the functionality of technology must correspond to the task requirements of the user. IS practitioners can explain why a planned system may not be fully acceptable to users, take corrective measures to improve the acceptability of $\mathrm{M}$-commerce, and determine ways to improve M-commerce adoption and its proper level of technological sophistication in order to increase business impact. Based on the results in this study, user acceptance of M-commerce can be improved when developers put their limited 
implementation resources to act on users' attitude toward M-commerce, and check whether TTF is appropriate or not. One way to improve TTF is to adopt a participatory design process for M-commerce.

The results point out that in order to truly exploit the latent large-scale operational and strategic potential benefits of M-commerce, business firms need to plan systematically and pursue a more extensive implementation of $\mathrm{M}$-commerce via an increase in the TTF and in the utilization of Mcommerce transactions. Expanding sophistication of user functions through integrated services, and making systems user-friendly also contribute to increased sales through M-commerce. Customer service can be improved by better access to information, availability and quick response to changing customer needs, faster information retrieval and delivery systems, and increased volume of information output. In general, these findings regarding the relationships among TTF, M-commerce utilization, and performance support the large body of research that focuses on the relationship between IS implementation and performance (Mahmood \& Mann, 1993; Weill, 1992).

Mobile commerce in Korea is still in its embryonic stage. The vast majority of mobile commerce service has been around only in the last few years. Many Korean companies consider M-commerce as a strategic information technology that alters the ground rules by which businesses interact with their consumers. Not enough has been understood about the real impact of this rapidly evolving phenomenon, particularly in terms of differentiating between impact and hype concerning the Internet. The results of this study can improve our understanding of the factors affecting $\mathrm{M}$ commerce success.

A majority of companies use $\mathrm{M}$-commerce as a medium for online selling and as a means to attract more customers. The average level of system sophistication, however, is generally low. This shows that many firms still significantly use other means of communication, such as faxes and phones, when their information exchange and processing can be handled through the increasingly convenient mobile communication services. Also, they still do not have integrated internal applications. This is interesting in light of past predictions that more exchanges between firms and customers would be made possible through electronic communication technologies due to more reliable communication networks.

This study supports the positive influence of the use of M-commerce on individual user performance. The mobile service providers should know subscriber demands, and develop the corresponding services, user interfaces, and mobile Internet settings. Increasing M-commerce volume can replace traditional means of commerce, and supports various business transactions through the Internet. M-commerce businesses must expand their connections 
with customers through the Internet in order to increase system profitability and improve customer service. Sophistication in system functions, including authentication of services and integration with internal applications, raises the benefits of reduced system operation and maintenance costs, and increased sales and profitability. If firms can provide information on their products and services in less time, they will have the ability to make better managerial decisions sooner, allowing them to react more quickly to threats and opportunities in the marketplace. M-commerce should be successfully assimilated into the work behaviors of target businesses early for them to realize its vast potential. Given the early stage of Internet use and the low extent of $\mathrm{M}$-commerce implementation, future research should investigate on a long-term basis the impact of $\mathrm{M}$-commerce on corporate outcome. Although M-commerce adoption among various industry sectors has been growing, high diffusion levels have yet to be reached.

This study may be a starting point for future M-commerce implementation studies. Future studies should include items that will reflect either "quality of web information" or "quality of web page/site design" of M-commerce ventures, and examine appropriate design characteristics related to M-commerce performance. The research findings suggest a need for future studies that will examine the internal and external environmental factors of an organization (e.g., top management support, size, compatibility, competitive intensity, and government support), which influence the implementation of M-commerce. This will help identify factors that may influence consumer views toward the desirability of online shopping. Further, the research results should be verified by other methods, such as using data collected in other countries, or by utilizing longitudinal data. Mcommerce in Korea is developing rapidly. Its expansion largely depends on external pressures, such as government policy and regulation, and influential trading partners. With the results reflecting the state of M-commerce in Korea, they may be limited to generalizing M-commerce results in other countries. Any attempt to generalize the findings among $\mathrm{M}$-commerce systems operating in different environments must be undertaken with care and caution. The results of this study may only be reflective of the unique characteristics of Korean M-commerce companies.

\section{ACKNOWLEDGEMENTS}

We would like to express our gratitude to Korean Research Foundation since this work was supported by Korea Research Foundation Grant (KRF2003-042-B00047). 


\section{REFERENCES}

Applegate, L.M. Holsapple, C.W., Kalakota, R., Radermacher, F.J., and Whinston, A.B., "Electronic commerce: building blocks of new business opportunity," Journal of Organizational Computing and Electronic Commerce, 6 (1), 1996, 1-10.

Bailey, M.N. and Lawrence, R.Z., "Do We have a New Economy," The American Economic Review, 91(2), 2001, 308-312.

Baldwin, N.S. and Rice, R.E., "Information-seeking behavior of securities analysts: individual and institutional influences, information sources and channels, and outcomes," Journal of the American Society for Information Science, 48, 8, 1997, 674-493.

Barnes, S.J., "The mobile commerce value chain: Analysis and future developments," International Journal of Information Management, 22(2), 2002, 91-108.

Benbasat, I. and Dexter, A.S., "An investigation of the effectiveness of color and graphical presentation under varying time constraints," MIS Quarterly, March 1986, 59-84.

Benbasat, I., Dexter, A.S., and Todd, P., "An experimental program investigating colorenhanced and graphical information presentation: An integration of the findings," Communications of the ACM, 29, 11, November, 1986, 1094-1105.

Blalock, H.M., Theory Construction: from Verbal to Mathematical Formulations, PrenticeHall, Englewood Cliffs, NJ, 1969.

Brancheau, J.C. and Wetherbe, J.C., "The adoption of spreadsheet software: Testing innovation diffusion theory in the context of end-user computing," Information Systems Research, 1, 2, 1990, 115-143.

Cho, N.J., "Internet business in Korea: the state-of-art," Management and Computer, September, 1999, 188-220.

Cooper, R.B. and Zmud, R.W., "Information technology implementation research," Management Science, 36 (2), 1990, 123-139.

Creyer, E.H., Bettman, J.R., and Payne, J.W., "The impact of accuracy and effort feedback and goals on adaptive decision behavior," Journal of Behavioral Decision Making, 3, 1, 1990, 1-16.

Culnan, M.J., "Environmental scanning: The effects of task complexity and source accessibility on information gathering behavior," Decision Sciences, 14, 2, April, 1983, 194-206.

Daft, R.L. and Macintosh, N.B., "A tentative exploration into the amount and equivocality of information processing in organizational work units," Administrative Science Quarterly, 26, 1981, 207-224.

Davis, F.D., "Perceived usefulness, perceived ease of use, and user acceptance of information technology," MIS Quarterly, 13, 1989, 319-339.

Davis, F.D., R.P. Bagozzi, and P.R. Warshaw, "User acceptance of computer technology: A comparison of two theoretical models," Management Science, 35, 8, 1989, 982-1003.

Dearle, A., "Toward ubiquitous environments for mobile users," IEEE Internet Computing, 2, 1, 1998, 22-32

DeLone, W. H. and McLean E. R.. Information systems success: The quest for the dependent variable. Information systems Research, 3 (1), 1992, 60-95.

DeSanctis, G., "Expectancy theory as an explanation of voluntary use of a decision support system," Psychological Reports, 52, 1983, 247-260.

Dickson, G.W., DeSanctis, G. and McBride, D.J., "Understanding the effectiveness of computer graphics for decision support: A cumulative experimental approach," Communication of $A C M, 29,1986,40-47$.

Fernandez, A., "The future of mobile telephony," Presentation to Mobile Telephony and Communications, Madrid, Spain May 2000, 22-23

Floyd, S.W., "A causal model of managerial electronic workstation use," unpublished doctoral dissertation, University of Colorado at Boulder, Boulder, CO, 1986.

Forrester Research, "USD7 trillion in e-commerce revenues by 2004," http://www.nua.ie/surveys/index.cgi?f=VS\&art id=905355736\&rel=true, accessed 21, April 2003.

Fuerst, W.L. and Cheney, P.H., "Factors affecting the perceived utilization of computer-based decision support systems in the oil industry," Decision Sciences, 13, 1982, 554-569.

Franz, C.R. and Robey, C., "Organizational context, user involvement, and the usefulness of information systems," Decision Science, 17, 1986, 329-356.

Ginzberg, M.J., "Finding an adequate measure of OR/MS effectiveness," Interfaces, 8 (4), August 1978, 59-62. 
Goodhue, D.L., "IS attitudes: Toward theoretical and definition clarity," Database, 19, 3/4, Fall/Winter 1988, 6-15.

Goodhue, D.L., "Understanding user evaluations of information systems," Management Science, 41 (12), December 1995, 1827-1844.

Goodhue, D.L. and Thompson, R.L., "Task-technology fit and individual performance," MIS Quarterly, 19, 2, June 1995, 213-236.

Goodhue, D.L., "Development and measurement validity of a task-technology fit instrument for user evaluations of information systems," Decision Sciences, 29, 1, Winter 1998, 105138.

Hair, J.F., Jr., Anderson, R.E., Tatham, R.L., and Grablowsky, B.J., Multivariate Data Analysis. Tulsa, OK; PPC Books, 1979.

Hage, J. and Aiken, M., Social Changes in Complex Organizations, New York, Random House, 1970.

Hartwick, J. and Barki, H., "Explaining the role of user participation in information system use," Management Science, 40 (4), 1994, 440-465.

Haskin, D., "Analysts: Smart phones to lead e-commerce explosion," allNetDevices, http://www.allnetdevices.com/news/9911/991103ecomm/991103ecomm.h tml, 3, November 1999,

Hoffer, J.A. and Alexander, M.B., "The diffusion of database machines," Data Base, 23 (2), 1992, 13-20.

Iacovou, C.L., Benbasat, I., and Dexter, A.S., "Electronic data interchange and small organizations: adoption and impact of technology," MIS Quarterly, 19 (4), 1995, 465-485.

Jarvenpaa, S.L., "The effect of task demands and graphical format on information processing strategies," Management Science, 35 (3), March 1989, 285-303.

Jarvenpaa, S.L. and Ives, B., "Organization for global competition: The fit of information technology," Decision Science, 24(3), 547-480, 1991.

Kalakota, R. and Whinston, A.B., Frontiers of Electronic Commerce, Addison-Wesley Publishing Company, Inc, 1996.

Kim, K., "Organizational coordination and performance in hospital accounting information systems: An empirical investigation," The Accounting Review, 63 (3), 1988, 472-488.

King, W.R. and Rodriguez, J.I., "Participative design of strategic decision support systems: An empirical assessment," Management Science, 27, 1981, 717-726.

Korea Internet Information Center (KIIC), Statistics of Internet Users, www.nic.or.kr, 2001.

Lai, V.S., "A contingency examination of CASE-task fit on software developer's performance," European Journal of Information Systems, 8, 1999, 27-39.

Lee, S.M., Kim. Y.R., and Lee. J.J., "An empirical study of the relationships among end-user information systems acceptance, training, and effectiveness," Journal of Management Information Systems, 12, 2, Fall 1995, 189-202.

Mahmood, N.A. and Mann, G.J., "Impact of information technology investment: An empirical assessment," Accounting, Management, and Information Technologies, 3 (1), 1993, 25-32.

Malone, T.W., "Toward a theory of intrinsically motivating instruction," Cognitive Science, 4, 1981, 333-369.

Mathieson, K., "Predicting user intentions: Comparing the technology acceptance model with the theory of planned behavior," Information Systems Research, 2 (3), September 1991, 173-191.

Mandry, T., G.Rohm, A.W., "Mobile agents in electronic markets: Opportunities, risks, agent protection," International Journal of Electronic Commerce, 5 (2), 2001, 47-60.

Moon, H.J. and Ahn, J.H., "Enhanced competitive edge through cybertrading system: A case of Daishin Securities Co., Ltd," Information Systems Review, 1 (2), 1999, 1 -20,.

Moore, G.C., "End user computing and office automation: A diffusion of innovations perspective," INFOR, 25 (3), 1987, 214-235.

Moore, G.C. and Benbasat, I., " Development of an instrument to measure the perceptions of adopting an information technology innovation," Information Systems Research, 2 (3), 1991, 192-222.

Nielsen, J., "Graceful degradation of sclalble internt services, WAP: Wrong approach to portability," Alertbox, www.useit.com/alertbox/991031.html, 31 October 1999.

Nilikanta, S. and Scammel, R.W., "The effect of information sources and communication channels on the diffusion of innovation in a database development environment," Management Science, 36 (1), 1990, 24-40. 
Omicini, A. and Zambonelli, F., "Co-ordination of mobile information agents in TuCSoN," Internet Research: Electronic Networking Applications and Policy, 8 (5), 1998, 400-413.

Perrow, P., "A framework for the comparative analysis of organization," American Sociological Review, 32(2), 1967, 194-208.

Premkumar, G., Ramamurthy, K., Nilakanta, S., "Implementation of electronic data interchange: an innovation diffusion perspective," Journal of Management Information Systems, 11 (2), 1994, 157-186.

Raymond, L., Pare, G., and Bergeron, F., "Matching information technology and organizational structure: An empirical study with implications for performance," European Journal of Information Systems, 4, 1994, 3-16.

Reynolds, F., Hjelm, J., Dawkins, S., and Singhal, S., "Composite capability / preference profiles (CC/PP): A user side framework for content negotiation," W3C Note, http://web4.w3.org/TR/Note-CCPP/, 1999

Senn, J.A., "The emergence of M-commerce," Computer, p. 148-150, December 2000.

Slack, F. and Rowley, J., "Online kiosks: The alternative to mobile technologies for mobile users," Internet Research: Electronic Networking Applications and Policy, 12 (3), 2002, 248-257.

Srinivasan, A., "Alternative measures of system effectiveness: associations and implications," MIS Quarterly, 9, September 1985, 243-253.

Strategy Analytics, "Strategy analytics forecasts $\$ 200$ billion mobile commerce market by $2004, "$ http://www.wowcom.com/newsline/press release.cfm?press $\mathrm{id}=862$, accessed 10 , July 2000 .

Swanson, E.B., "Information systems innovation among organizations," Management Science, 40 (9), September 1994, 1069-1092.

Thompson, R.L., Higgins, C.H., and Howell, J.M., "Personal computing: Towards a conceptual model of utilization," MIS Quarterly, 15 (1), March 1991, 125-143.

Thompson, R.L., Higgins, C.A., and Howell, J.M., "Influence of experience on personal computer utilization: Testing a conceptual model," Journal of Management Information Systems, 11(1), 1994, 167-187,.

Tornatzky, L.G. and Klein, K.J., "Innovation characteristics and innovation adoptionimplementation: A meta-analysis of findings," IEEE Transactions on Engineering Management, 29 (1), February 1982, 28-45.

Trice, A.W. and Treacy, M.E., "Utilization as a dependent variable in MIS research," Data Base, 19(3/4), Fall/Winter 1988.

Varshney, U., "Multicast support in mobile commerce applications," Computer, February 2001, 115-117.

Varshney, U. and Vetter, R., "A framework for the emerging mobile commerce applications," Proceedings of the 34th Hawaii International Conference on System Sciences, 2001.

Mũller-Veerse, F., "Mobile Commerce Report," Durlacher Corp., London, http://www.durlacher.com/ downloads/mcomreport.pdf, accessed 2002.

Vertinsky, I, Barth, R.T., and Mitchell, V.F., "A study of OR/MS implementation as a social change process," In R.L. Schultz \& D.P. Slevin (eds.), Implementing Operations Research/Management Science, American Elsevier, New York, 1975, 253-272.

Vessey, I., "Cognitive fit: A theory-based analysis of the graphs vs. tables literature," Decision Sciences, 22 (2), Spring 1991, 219-240.

Vitale, M.R., "American Hospital Supply Corp.: the ASAP system," Harvard Business School Case, Services No. 9-186-005, Harvard University, Boston, 1985.

Wearden, G., "UK mobile phone users hits 40 million," http://www.zdnet.co.uk/news/ $2001 / 0 /$ ins-20014 html, accessed 2 February 2001

Weill, P., "The relationship between investment in information technology and firm performance: A study of the valve manufacturing sector," Information Systems Research, 3 (4), 1992, 307-333.

Withey, M., Daft, R.L., and Cooper, W.H., "Measures of Perrow's work unit technology: An empirical assessment and a new scale," Academy of Management Journal, 26(1), 1983, 4563 . 